\title{
INFLUENCE OF WINDOW TYPE ON THE AIRTIGHTNESS OF RESIDENTIAL UNITS
}

\author{
Hrvoje Krstić \\ Josip Juraj Strossmayer University of Osijek, Faculty of Civil Engineering Osijek, Assistant Professor \\ Corresponding author: hrvojek@gfos.hr \\ Željko Koški \\ Josip Juraj Strossmayer University of Osijek, Faculty of Civil Engineering Osijek, Associate Professor \\ MatijaTomljanović \\ Josip Juraj Strossmayer University of Osijek, Faculty of Civil Engineering Osijek, mag.ing.aedif.
}

\begin{abstract}
Airtightness plays a significant role in the energy efficiency of buildings. In this paper, we investigated how varying the type of window affects the airtightness values of residential units. We studied three sets of residential units, each comprising two residential units with the same geometry and year of construction, varying only the installed window type and window-frame material. A brief explanation is included of the blower-door method, used in field-testing the airtightness of residential units. Replacing the old windows in the residential units with newer windows significantly improved the airtightness. To generalize these results, further research is needed with larger samples.
\end{abstract}

Keywords: airtightness, residential units, windows, energy efficiency

\section{UTJECAJ RAZLIČITIH VRSTA PROZORA NA VRIJEDNOSTI ZRAKOPROPUSNOSTI STAMBENIH JEDINICA}

Sažetak: Zrakopropusnost igra značajnu ulogu u energetskoj učinkovitosti zgrada. U radu se nastoji istražiti utjecaj različitih prozirnih obodnih konstrukcija zgrade - prozora, na zrakopropusnost stambenih jedinica, što je vrlo važno kada se u obzir uzmu energetska učinkovitost i prikladna toplinska ugodnost. U radu su uspoređene vrijednosti zrakopropusnosti na tri različita seta stambenih jedinica, od kojih svaki set sadrži dvije stambene jedinice izgrađene iste godine i jednakih geometrijskih karakteristika. Jedina razlika između stambenih jedinica u ovom radu je u vrsti prozora i materijalu okvira od kojih su načinjeni prozori. Prva stambena jedinica u svakom setu je s originalnim, starim prozorima, a druga jedinica je s novim, zamijenjenim prozorima. U radu je kratko objašnjena Blower Door metoda i uređaj koji se koristi za terenska ispitivanja zrakopropusnosti stambenih jedinica. Rezultati prikazani u radu ukazuju na trend značajnog poboljšanja vrijednosti zrakopropusnosti u stambenim jedinicama s novijim prozorima. Za generalizaciju dobivenih rezultata potrebno je provesti mjerenja zrakopropusnosti na većem uzorku stambenih jedinica.

Ključne riječi: zrakopropusnost, stambene jedinice, prozori, energetska učinkovitost 


\section{INTRODUCTION}

The ever-growing demand for energy requires new technologies for utilizing renewable energy, as well as rational consumption of available energy. Sustaining and developing global civilization depends on the providing sufficient cheap energy while protecting the environment.

Buildings are complex energy systems and the greatest individual consumers of energy, and the European building sector is responsible for consuming about $40 \%$ of all primary energy [1]. This energy is partly wasted because buildings constructed several decades ago do not meet the energy efficiency requirements of current legislation in the European Union. Many of these buildings will continue to be used for many more years; unless their energy performance is improved, they will continue to needlessly consume massive amounts of energy for heating, cooling, appliance operation, and lighting.

In building design, it is rational to combine insulation with air-tightening of the building envelope [2]. Airtightness is an important factor that affects the energy efficiency, thermal comfort, and indoor air quality of buildings, so understanding airtightness is important for designing new buildings and retrofitting existing buildings [3]. When measuring the airtightness of buildings, a blower door is used to assess the relationships between the pressure difference over the building envelope, $\Delta \mathrm{P}[\mathrm{Pa}]$, and the air flow rate through the building envelope, $\mathrm{Q}$ $\left[\mathrm{m}^{3} / \mathrm{h}\right]$ [4]. The "building envelope" refers to several types of opaque and transparent perimeter structures or elements, which separate the internal heated (cooled) space from the external unheated (uncooled) space.

This research clarifies how changing the transparent perimeter structures of residential units affects their airtightness values. We accomplished this by field-testing the airtightness values of three pairs of residential buildings, each comprising two residential units with same geometry and year of construction, differing only the window type, window age, and the window-frame material. In each set, the first unit had the original, old windows, and the second unit had new, replaced windows.

\section{PREVIOUS RESEARCH}

Many factors affect the airtightness values of buildings, including their window type, frame materials, and building age. Because of the ever-increasing demands for cooling buildings by mechanical means, Sfakianaki et al. studied the airtightness of 20 houses in Greece [5]. They found a correlation, at a pressure difference of $50 \mathrm{~Pa}$, between the airtightness and the total length of the window frames, mainly in "low airtightness" buildings. However, this sample is very small, and many more experiments are required.

A study in Great Britain assessed the airtightness of 287 residential units constructed after 2006 [6], finding the average air permeability of UK dwellings to be $5.97 \mathrm{~m}^{3} /\left(\mathrm{h} \mathrm{m}^{2}\right)$ at $50 \mathrm{~Pa}$, much better than values found in older buildings and previous research [6]. The newly build UK dwellings were more airtight than those in some other countries, including Greece and the US, but they were still significantly leakier than those in Canada and Scandinavia.

Figure 1 shows how the airtightness of buildings in Croatia has improved over the years, which is expected because of advances in construction design and technology [2].

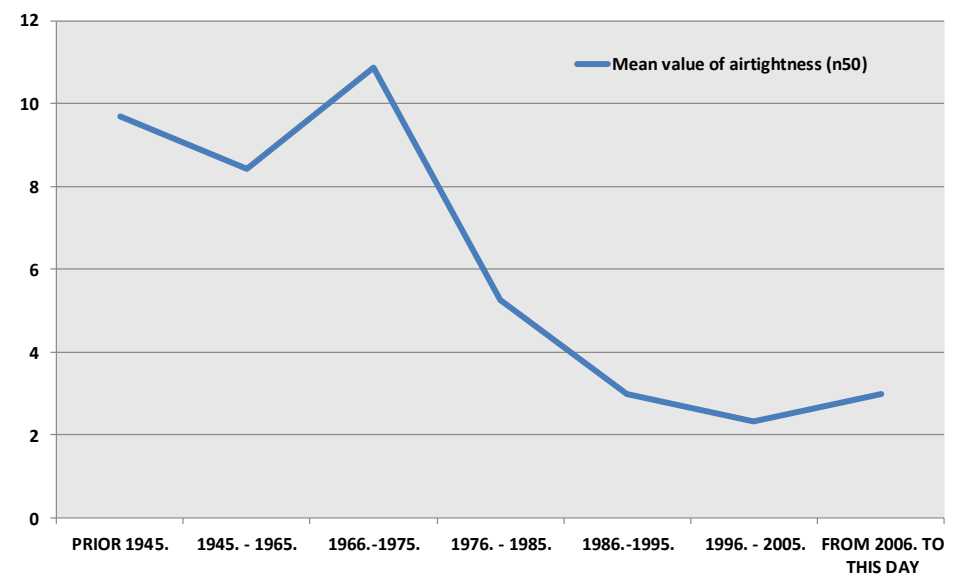

Figure 1 Mean airtightness $\left(\mathrm{n}_{50}\right)$ by construction period [2] 
A building's airtightness directly affects it heat losses; uncontrolled air exchange dramatically increases heating requirements. Figure 2 shows the relationship between heat losses $\left[\mathrm{kWh} / \mathrm{m}^{2} \mathrm{a}\right]$ and air changes $[1 / \mathrm{h}]$ in buildings.

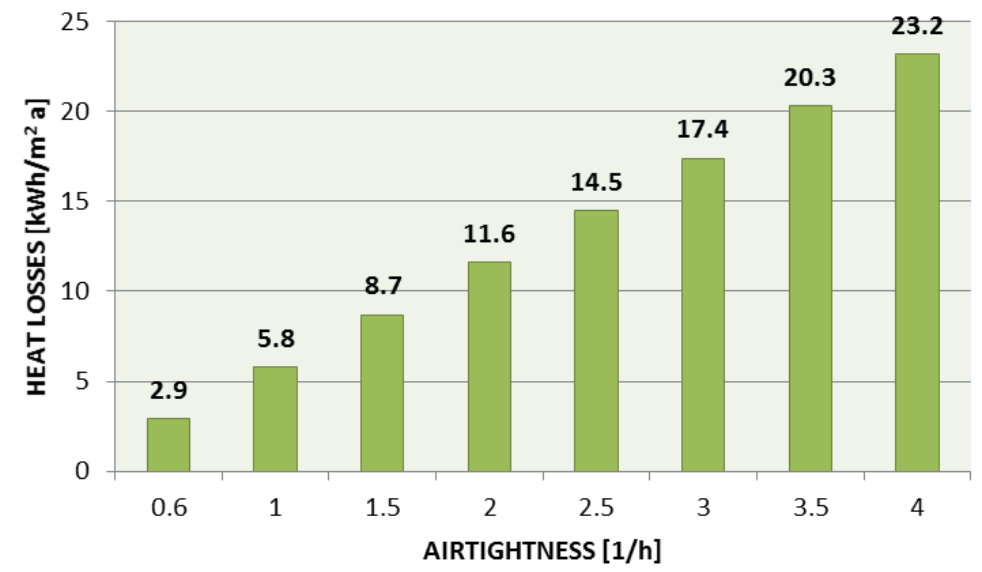

Figure 2 Relationship between specific heat demand and air changes [7]

Airtightness can be affected by the design and management concept, design details, structure type, construction method, type of thermal insulation, number of storeys, surface area of the building envelope, floor area, construction quality and supervision, season, climate, maintenance, type of unit, joinery, frame materials, window frame length, total frame length, building age, number of significant cracks, and management context [2]. values.

This paper analyzes how the window age, window-frame materials, and building age affect airtightness

\section{RESIDENTIAL UNITS AIRTIGHTNESS MEASUREMENTS}

The term "airtightness" pertains to the intensity of the uncontrolled flow of air through the building envelope, caused by a pressure difference between the interior and exterior air. Uncontrolled leakage of air can occur through joints, connections between different materials, dilatations, and other permeable points in the building envelope. Building regulations often give airtightness requirements [4]. Airtightness is most often measured by the pressure difference method (the blower door test), described in detail in the HRN EN 13829:2002 standard (Thermal performance of buildings - Determination of airtightness of buildings - Fan pressurization method). In the Republic of Croatia, this method is described by a technical regulation related to rational use of energy and thermal protection in buildings (Official Gazette No. 97/14). In this report, we measured airtightness by using a blower door in accordance with EN ISO 13829.

All our experimental results were acceptable because they fulfill the EN ISO 13829 criteria [5]:

- $\quad$ the wind speed must be lower than $6 \mathrm{~m} / \mathrm{s}$

- $\quad$ the product of the maximum building height [m]and the temperature difference between outdoor and indoor dry bulb temperatures must be lower than $500 \mathrm{mK}$

- $\quad$ the building's volume must be less than $4000 \mathrm{~m}^{3}$

EN ISO 13829 describes two methods, used depending on the purpose $[8,9]$ :

- Method A - The condition of the external building envelope must be representative for the season when heating or cooling systems are used, without additional sealing.

- Method B - All the designed openings in the building envelope must be sealed.

We used method A (common building use) of EN ISO 13829 while also applying a pressure difference of 50 $\mathrm{Pa}$ to fulfill the requirements of EN ISO 13790. Prior to measuring the airtightness of buildings, one must gather the required data on the floor area and volume, as well as the surface area of the envelope building.

The measurement device is connected to a computer via a USB port and uses TECTITE Express 3.6 software. After installing the program and entering the required data, the device measures the initial pressure difference between the exterior and interior space, which cannot exceed $5 \mathrm{~Pa}$. If the difference is greater than that, 
the measurement must be repeated or postponed until the wind-which significantly influences the pressure difference-recedes. We measured the airtightness using a DG-700 Minneapolis Blower Door, shown in Figure 3.

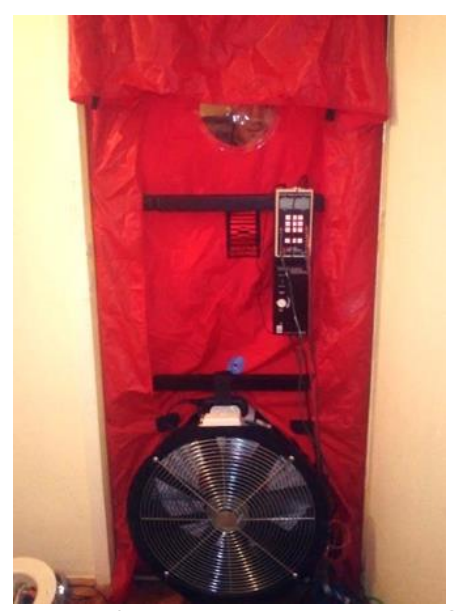

Figure 3 Blower door fan with manometer DG-700 [10]

Airtightness results are often presented in one of the following ways [11]:

- $\quad \mathrm{n}_{50}, \mathrm{ACH}$ at 50 pascals: The air changes per hour at 50 pascals, applied uniformly across the building envelope.

- $\quad q_{50}$, flow at 50 pascals / unit surface area: The flow at 50 pascals divided over the surface area of the building or unit envelope. This calculation adjusts (or normalizes) the building leakage rate by the surface area of the building.

These measurements were conducted during 2013 and 2014 in Osijek. Three sets of residential units were chosen, each set comprising two identical residential units. Table 1 shows the characteristics of the residential units from all three sets. As Table 1 shows, the following properties of both residential units were identical: volume, surface area, floor area, year of construction, area of the transparent part of the residential unit envelope, layers in external walls, and ceiling type. The only differences between units in each set were the window glazing and frame material. The renovated units had new windows installed after 2005, replacing the original, old windows from when the buildings were constructed.

Table 1 Characteristics of residential units

\begin{tabular}{|c|c|c|c|c|c|c|c|c|c|c|}
\hline 㤐 & $\begin{array}{l}\text { Residential } \\
\text { unit }\end{array}$ & 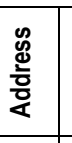 & $\begin{array}{l}\text { Volume } \\
{\left[\mathrm{m}^{3}\right]}\end{array}$ & $\begin{array}{l}\text { Surface } \\
\text { area } \\
{\left[\mathrm{m}^{2}\right]}\end{array}$ & $\begin{array}{l}\text { Floor } \\
\text { area } \\
{\left[\mathrm{m}^{2}\right]}\end{array}$ & $\begin{array}{l}\text { Year of } \\
\text { constr. }\end{array}$ & $\begin{array}{c}\text { Area of } \\
\text { transparent } \\
\text { part of } \\
\text { envelope }\left[\mathrm{m}^{2}\right] \\
\end{array}$ & External walls & $\begin{array}{l}\text { Type of } \\
\text { ceiling }\end{array}$ & $\begin{array}{l}\text { Material and } \\
\text { joinery type }\end{array}$ \\
\hline \multirow{2}{*}{ 㤐 } & $\begin{array}{l}\text { Residential } \\
\text { unit } 1.1 \text { - non } \\
\text { renovated unit }\end{array}$ & \multirow{2}{*}{ 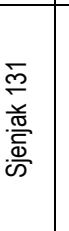 } & \multirow[b]{2}{*}{185.0} & \multirow[b]{2}{*}{241.0} & \multirow[b]{2}{*}{71.0} & \multirow[b]{2}{*}{1977} & \multirow[b]{2}{*}{26.17} & \multirow{2}{*}{$\begin{array}{c}\text { mortar }(2 \mathrm{~cm})+ \\
\mathrm{RC}(15 \mathrm{~cm})+ \\
\text { expanded } \\
\text { polystyrene EPS } \\
(5 \mathrm{~cm})\end{array}$} & \multirow[b]{2}{*}{ RC slab } & $\begin{array}{l}\text { Wood, double } \\
\text { glazing }\end{array}$ \\
\hline & $\begin{array}{l}\text { Residential } \\
\text { unit } 1.2- \\
\text { renovated unit }\end{array}$ & & & & & & & & & $\begin{array}{l}\text { PVC, double- } \\
\text { insulated glass } \\
\text { with a sealed } \\
\text { layer of air }\end{array}$ \\
\hline \multirow{2}{*}{ 点 } & $\begin{array}{l}\text { Residential } \\
\text { unit } 2.1 \text { - non- } \\
\text { renovated unit }\end{array}$ & \multirow{2}{*}{ 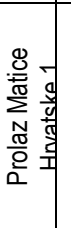 } & \multirow[b]{2}{*}{155.0} & \multirow[b]{2}{*}{222.0} & \multirow[b]{2}{*}{59.0} & \multirow[b]{2}{*}{1964} & \multirow[b]{2}{*}{16.71} & \multirow{2}{*}{$\begin{array}{c}\text { mortar }(2 \mathrm{~cm})+ \\
\text { solid brick }(25 \\
\mathrm{cm})+ \text { expanded } \\
\text { polystyrene EPS } \\
(6 \mathrm{~cm})\end{array}$} & \multirow[b]{2}{*}{ RC slab } & $\begin{array}{l}\text { Wood, double } \\
\text { glazing }\end{array}$ \\
\hline & $\begin{array}{c}\text { Residential } \\
\text { unit } 2.2 \text { - } \\
\text { renovated unit }\end{array}$ & & & & & & & & & $\begin{array}{c}\text { ALU, PVC, } \\
\text { double-insulated } \\
\text { glass with a } \\
\text { sealed layer of air }\end{array}$ \\
\hline \multirow[b]{2}{*}{ 点 } & $\begin{array}{l}\text { Residential } \\
\text { unit } 3.1 \text { - non- } \\
\text { renovated unit }\end{array}$ & \multirow{2}{*}{ 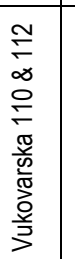 } & \multirow[b]{2}{*}{144.0} & \multirow[b]{2}{*}{235.0} & \multirow[b]{2}{*}{57.0} & \multirow[b]{2}{*}{1964} & \multirow[b]{2}{*}{11.76} & \multirow{2}{*}{$\begin{array}{c}\text { mortar }(2 \mathrm{~cm})+ \\
\text { solid brick }(25 \\
\mathrm{cm})+ \text { mortar }(2 \\
\mathrm{cm})\end{array}$} & \multirow[b]{2}{*}{ RC slab } & $\begin{array}{l}\text { Wood, double } \\
\text { glazing }\end{array}$ \\
\hline & $\begin{array}{l}\text { Residential } \\
\text { unit } 3.2 \text { - } \\
\text { renovated unit }\end{array}$ & & & & & & & & & $\begin{array}{l}\text { PVC, double } \\
\text { insulated glass } \\
\text { with a sealed } \\
\text { layer of air }\end{array}$ \\
\hline
\end{tabular}


Table 2 shows the measured airtightness values of the residential units; for each set, it gives the air changes per hour at 50 pascals $\left(n_{50}\right)$ as well as the flow at 50 pascals divided by the surface area of the residential unit $\left(q_{50}\right)$.

These results show that replacing the old, original windows in the residential units with new windows greatly decreased the airtightness values.

Table 2 Airtightness of residential units

\begin{tabular}{|c|c|c|c|}
\hline 岕 & Residential unit & $\mathrm{n}_{50}$ (Air changes per hour) [1/h] & $q_{50}\left[\mathrm{~m}^{3} / \mathrm{hm}^{2}\right]$ \\
\hline \multirow{2}{*}{ 点 } & Residential unit 1.1 - non renovated unit & 5.73 & 4.4 \\
\hline & Residential unit 1.2 - renovated unit & 0.94 & 0.72 \\
\hline \multirow{2}{*}{ 点 } & Residential unit 2.1 - non renovated unit & 6.39 & 4.46 \\
\hline & Residential unit 2.2 - renovated unit & 1.13 & 0.79 \\
\hline \multirow{2}{*}{ 点 } & Residential unit 3.1 - non renovated unit & 8.2 & 5.04 \\
\hline & Residential unit 3.2 - renovated unit & 1.14 & 0.88 \\
\hline
\end{tabular}

\section{DISCUSSION}

Using the airtightness results, we analyzed the airtightness of each building set by calculating the relative reduction in airtightness ( $n_{50}$ and $\left.q_{5} 0\right)$, as shown in Table 3.Table 3 shows the measured properties of the mixtures.

Table 3 Airtightness reduction in building sets

\begin{tabular}{|c|c|c|}
\hline Residential unit sets & Difference $\mathrm{n}_{50}[\%]$ & Difference $\mathrm{q}_{50}[\%]$ \\
\hline SET 1 & $-83.60 \%$ & $-83.64 \%$ \\
\hline SET 2 & $-82.32 \%$ & $-82.29 \%$ \\
\hline SET 3 & $-86.10 \%$ & $-82.54 \%$ \\
\hline
\end{tabular}

In this study, the old wooden windows were replaced with new PVC windows with double-insulated glass with a sealed layer of air, reducing airtightness by $\sim 3 \%$ in all residential unit sets to an average $n_{50}$ of 1.07 .

We compared the airtightness $\left(n_{50}\right)$ of the renovated units to the mean airtightness for buildings constructed in various time period, as shown in Figure 4. Set 1 is from 1976-1985, and sets 2 and 3 are from 1966-1975. The airtightness values for all sets decreased, but for sets 2 and 3 they decreased by $\sim 90 \%$, demonstrating great promise for energy savings.

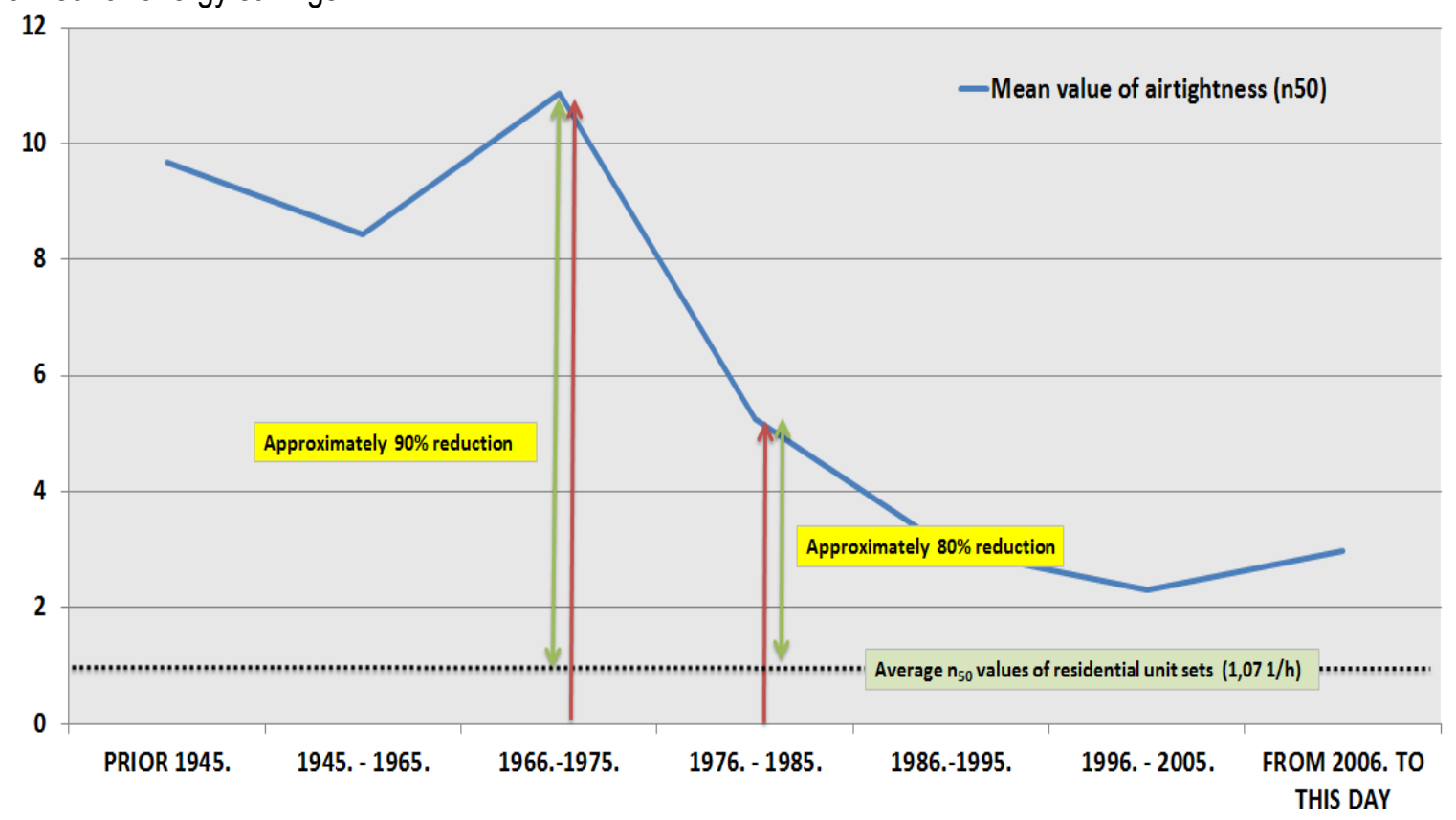

Figure 4 Potential reductions in airtightness by construction period 
Replacing old windows with new ones also affected the heat losses in residential units, as demonstrated in Figure 2. Table 4 shows these heat losses, demonstrating that the heat losses in the non-renovated units were caused by higher airtightness values compared with those of the renovated units. Replacing old windows with new ones saved vast amounts of energy: in this study, heat losses decreased by $72.61-83.64 \%$.

Table 4 Heat losses of non-renovated and renovated units

\begin{tabular}{|l|c|c|c|c|}
\hline \multicolumn{4}{|c|}{ Heat losses of non-renovated and renovated units [kWh/m²a] } & Difference $\mathbf{n}_{50}$ [\%] \\
\hline Residential unit 1.1 - non renovated unit & $\mathbf{3 3 . 2 3}$ & Residential unit 1.2 - renovated unit & $\mathbf{5 . 3 7}$ & $83.84 \%$ \\
\hline Residential unit 2.1 - non renovated unit & $\mathbf{3 7 . 0 6}$ & Residential unit 2.2 - renovated unit & $\mathbf{1 0 . 1 5}$ & $72.61 \%$ \\
\hline Residential unit 3.2 -non renovated unit & $\mathbf{4 7 . 5 6}$ & Residential unit 3.1 - renovated unit & $\mathbf{1 0 . 1 4}$ & $78.68 \%$ \\
\hline
\end{tabular}

\section{CONCLUSION}

In this paper, we investigated how varying the type of window affects the airtightness values of residential units. Results from three sets of residential units were presented, each comprising two residential units with the same geometry and year of construction, varying only the installed window type and window-frame material.

By analyzing our results, we came to the following conclusions:

- Replacing old windows in the residential units with newer windows significantly improved airtightness, which affects heat losses

- Heat losses in the non-renovated units were caused by higher airtightness values compared to those of the renovated units

- $\quad$ Replacing old windows with new ones saved vast amounts of energy: in this study, heat losses decreased by $72.61-83.64 \%$

- To generalize these results, more research must be done with larger samples

By quantifying the energy savings in residential units, we found that replacing old windows with new ones improved energy efficiency. Further investigation should address how the installation quality of the windows and the frame material influence the airtightness values.

\section{References}

[1] Tommerup, H.; Rose, J.; Svendsen, S. 2007: Energy-efficient houses built according to the energy performance requirements introduced in Denmark in 2006, Energy and Buildings, Volume 39, Issue 10, pp. 1123-1130.

[2] Krstić, H. et al. 2014: Application of Neural Networks in Predicting Airtightness of Residential Units. Energy and Buildings.

[3] Sinnott, D; Dyer, M. 2012: Air-tightness field data for dwellings in Ireland, Building and Environment, Volume 51, pp. 269-275.

[4] Relander, T.-O.; Holøs, S.; Thue, J.V. 2012: Airtightness estimation-A state of the art review and an en route upper limit evaluation principle to increase the chances that wood-frame houses with a vapour- and windbarrier comply with the airtightness requirements, Energy and Buildings, Volume 54, pp. 444-452.

[5] Sfakianaki, A. et al. 2008: Air tightness measurements of residential houses in Athens, Greece, Building and Environment, Volume 43, Issue 4, pp. 398-405.

[6] Pan, W. 2010: Relationships between air-tightness and its influencing factors of post-2006 new-build dwellings in the UK, Building and Environment, Volume 45, Issue11, pp. 2387-2399.

[7] ISOVER 2014: Energy efficiency - Save money with ISOVER. Accessed 8 Nov 2014]. Available from: http://www.isover-airtightness.com/Benefits/Energy-efficiency.

[8] EN 13829:2002, Thermal performance of buildings - Determination of air permeability of buildings - Fan pressurization method (ISO 9972:1996, modified; EN 13829:2000), 2002.

[9] Tehnički propis o racionalnoj uporabi energije i toplinskoj zaštiti u zgradama (Translation: Technical regulation for rational use of energy and thermal insulation of buildings). „Narodne novine“ broj 97/14. Available from: http://narodne-novine.nn.hr/clanci/sluzbeni/2014_08_97_1938.html (in Croatian). 
[10] Tomljanović, M. 2014: Energy performance analysis of building envelope using blower door and thermographic procedures, Master's Thesis in Faculty of Civil Engineering Osijek, Josip Juraj Strossmayer University of Osijek: Osijek, p. 58.

[11] TECTITE Express Manual Ver 3.6. The Energy Conservatory. Accessed 15 Oct 2013. Available from: http://materialy.wb.pb.edu.pl/irenaickiewicz/files/2013/01/TECTITE-Express-Manual-Ver-3.6.pdf.IGH 2001: General technical requirements for roadwork, in Book III, Pavement structure (in Croatian). 